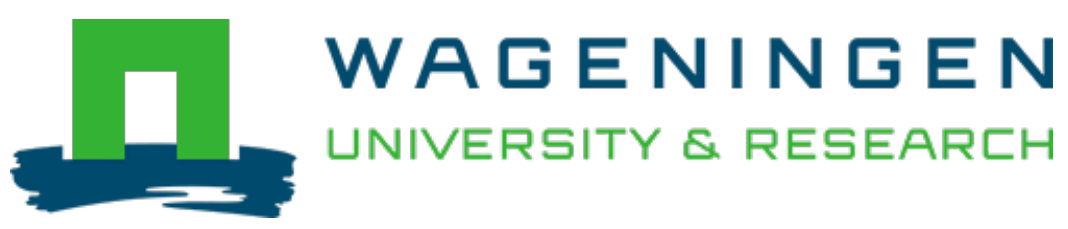

\title{
Frozen storage of lesser mealworm larvae (Alphitobius diaperinus) changes chemical properties and functionalities of the derived ingredients
}

\author{
Food Chemistry \\ Wessels, M.L.J.; Azzollini, D.; Fogliano, V. \\ https://doi.org/10.1016/j.foodchem.2020.126649
}

This article is made publicly available in the institutional repository of Wageningen University and Research, under the terms of article $25 \mathrm{fa}$ of the Dutch Copyright Act, also known as the Amendment Taverne. This has been done with explicit consent by the author.

Article 25 fa states that the author of a short scientific work funded either wholly or partially by Dutch public funds is entitled to make that work publicly available for no consideration following a reasonable period of time after the work was first published, provided that clear reference is made to the source of the first publication of the work.

This publication is distributed under The Association of Universities in the Netherlands (VSNU) 'Article $25 \mathrm{fa}$ implementation' project. In this project research outputs of researchers employed by Dutch Universities that comply with the legal requirements of Article $25 \mathrm{fa}$ of the Dutch Copyright Act are distributed online and free of cost or other barriers in institutional repositories. Research outputs are distributed six months after their first online publication in the original published version and with proper attribution to the source of the original publication.

You are permitted to download and use the publication for personal purposes. All rights remain with the author(s) and / or copyright owner(s) of this work. Any use of the publication or parts of it other than authorised under article $25 \mathrm{fa}$ of the Dutch Copyright act is prohibited. Wageningen University \& Research and the author(s) of this publication shall not be held responsible or liable for any damages resulting from your (re)use of this publication.

For questions regarding the public availability of this article please contact openscience.library@,wur.nl 


\title{
Frozen storage of lesser mealworm larvae (Alphitobius diaperinus) changes chemical properties and functionalities of the derived ingredients
}

\author{
M.L.J. Wessels, D. Azzollini, V. Fogliano* \\ Food Quality \& Design Group, Wageningen University \& Research. Bornse Weilanden 9. 6708 WG, Wageningen, The Netherlands
}

\section{A R T I C L E I N F O}

\section{Keywords:}

Edible insects

Lesser mealworm

Frozen storage

Ingredient functionalities

Protein aggregation

\begin{abstract}
A B S T R A C T
The effect of frozen storage on the chemical properties and ingredient functionalities of Lesser mealworms was investigated at $-20{ }^{\circ} \mathrm{C}$ for 2 months. Major changes occurred in the first week of frozen storage. Proteins, among which heavy chain myosin, underwent denaturation and aggregation, as shown by a decrease in solubility, SDSPAGE pattern, and Confocal Laser Scanning Microscopy. The ice melting point in larvae was $-32.5{ }^{\circ} \mathrm{C}$ as determined by DSC: $25 \%$ of water is not frozen at $-20{ }^{\circ} \mathrm{C}$, possibly due to anti-freezing proteins preventing ice formation. The presence of unfrozen water favoured various enzymatic activities as shown by a $\mathrm{pH}$ decrease, indicating protein hydrolysis. The molecular changes during frozen storage increased the browning reactions due to phenoloxidase activity. Foaming ability, foam stability and gel network stability increased upon frozen storage due to protein denaturation. Results provide important information regarding the opportunity of frozen storage of insect larvae for both research and industrial purposes.
\end{abstract}

\section{Introduction}

Edible insects are being increasingly researched as they are expected to offer nutritional and sustainable opportunities for enhancing the future food security (Van Huis et al., 2013). In insect industry, insects are killed by chilling to freezing temperature, then stored and transported at $-18{ }^{\circ} \mathrm{C}$ before processing (Ortiz et al., 2016). Chilling is in fact considered the most ethical way to sacrifice insects for food purposes, as they die without regaining consciousness (Dossey, Tatum, \& McGill, 2016). Therefore, the killing method, transport and storage handling determine the final product quality in the insect supply chain.

Recently, Leni, Caligiani, and Sforza (2019) found that the slow freezing method did not inactivate several enzymatic pathways, among them melanisation, resulting in more black protein fractions after extraction. These observations were not found if blanching was used as post-harvesting method. Additionally, the molecular changes occurring in frozen Yellow mealworms (Tenebrio molitor L.), suggested that freezing led to the breakdown of cell membrane.

Processing insects into food ingredients is the most promising direction for exploiting this new food source. Eating conventional products containing unrecognisable insects are more acceptable than whole insects for Western consumers. In this framework, research about insect ingredient functionalities is emerging (Azzollini, Wibisaphira,
Lakemond, \& Fogliano, 2018; Tzompa-Sosa, Yi, van Valenberg, \& Lakemond, 2019). However, several inconsistencies can be found in the literature. Yi et al. (2013) found that gel formation occurred in several insect species when $30 \% \mathrm{w} / \mathrm{v}$ soluble proteins were added at $\mathrm{pH} 7$. On the contrary, Janssen (2018) found that no gel could be formed with the soluble proteins of larvae of A. diaperinus at the same pH. Preliminary experiments showed differences in insect protein functionalities and colour development when larvae of Lesser mealworms and Yellow mealworms were stored at industrial freezing conditions of $-18{ }^{\circ} \mathrm{C} \pm 2$. Given the relevance of these findings, characterising these changes upon storage is of high relevance to ensure consistency in literature of insect ingredient functionalities.

Degradation of meat upon storage at freezing condition is a widely known phenomenon and it is mainly associated to the ice crystal growth. Fish muscle proteins are denatured during frozen storage and lose water. In salmon, for instance, the size of ice crystals increases salmon during storage at freezing temperature (Matsumoto, 1979). Also, myofibrillar proteins of meat tissues are denatured due to recrystallization of ice during storage (Ali et al., 2015; Syamaladevi, Manahiloh, Muhunthan, \& Sablani, 2012). In insects, the most important degradation factor during freezing storage can be the biological reactions due to unfrozen water. Several insect species contain antifreeze proteins (AFPs) that are able to bind to macromolecular ice and

\footnotetext{
Abbreviations:AFPs, Antifreeze proteins

* Corresponding author.

E-mail address: vincenzo.fogliano@wur.nl (V. Fogliano).
} 
therefore inhibit ice growth favouring enzymatic activities and other biological reactions (Graether \& Brian, 2004). Payne, Sandford, Harris, and Young (1994) found that AFPs reduce the size of ice crystals in frozen meat.

Thus far, little attention has been paid to the effect of storage conditions on the ingredient functionalities of insects. The aim of the current study was to investigate the chemical modification occurring during frozen storage (at minus $20^{\circ} \mathrm{C}$ ) of the Lesser mealworms and the consequences on the functionalities on the insect-based ingredients obtained by their fractionation.

\section{Materials and methods}

\subsection{Experimental plan}

Fresh larvae of Lesser mealworms, harvested at 28 days old after $24 \mathrm{~h}$ of fasting, were provided by Proti-Farm Holding NV (Ermelo, The Netherlands). Upon arrival, the larvae were snap frozen by liquid nitrogen and stored in sealed cups of $50 \mathrm{~g}$ at a temperature of $-20{ }^{\circ} \mathrm{C}$ for $1,7,14,32$ and 60 days. These points were taken based on preliminary experiments and working calendar. One sample was stored at $-80^{\circ} \mathrm{C}$ to simulate the reference at time 0 . At the sampling day, the corresponding cup of $50 \mathrm{~g}$ was moved from $-20{ }^{\circ} \mathrm{C}$ towards an ultra-low freezer at $-80{ }^{\circ} \mathrm{C}$ (EVOSAFE-SERIES ${ }^{\mathrm{TM}}$, Snijders LABS, Tilburg, NL) to avoid further modifications before analyses. The authors acknowledge that snap freezing in liquid nitrogen differs from the standard technique applied in industry, where slower freezing is employed. Nevertheless, fast freezing was used to focus on the aim of the paper (cold storage), to limit structural alterations that would occur upon slow freezing (e.g. formation of large ice crystals) and narrow the effects observed upon time to storage conditions.

\subsection{Sample preparation}

Cold conditions were used during the entire preparation of the larvae solution to minimize enzymatic activity during processing. These cold conditions were realised by keeping the samples always in ice during processing. Firstly, the frozen larvae were sieved to remove dust, faeces and feed. The solution was made by weighing $50 \mathrm{~g}$ of frozen larvae and $200 \mathrm{~mL}$ of $0.1 \mathrm{~mol} / \mathrm{L}$ potassium phosphate buffer at $\mathrm{pH} 7.0$ with a temperature of $4{ }^{\circ} \mathrm{C}$ (insect to solution ratio $1: 4 \mathrm{w} / \mathrm{v}$ ). The larvae were poured into the buffer solution while stirring to prevent large clump formations and blended by a hand blender (700 W, Grundig, Nürnberg, GER) for $1 \mathrm{~min}$ at turbo speed. After blending, the beaker was covered with aluminium foil and stirred with a magnet stirrer for $15 \mathrm{~min}$ at a speed of $250 \mathrm{rpm}$ to enhance protein solubility. The mixture was filtered by making use of a pre-soaked cheesecloth to remove residual solid particles. The suspension was put in $50 \mathrm{~mL}$ Greiner centrifuge tubes (CELLSTAR ${ }^{\oplus}$, Greiner Bio-One, NL) and centrifuged (Heraeus $^{\mathrm{TM}}$ Multifuge $^{\mathrm{TM}} \mathrm{X} 3 \mathrm{R}$, Thermo Fisher ${ }^{\mathrm{TM}}$ ) for $10 \mathrm{~min}$ at $4500 \mathrm{~g}$ at $4{ }^{\circ} \mathrm{C}$. After centrifugation, three layers were obtained (cream, supernatant, and pellet). They were weighed and the supernatant was used for all experiments described below. The moisture content of the supernatant of every sampling day was determined by drying at $105^{\circ} \mathrm{C} \pm 2{ }^{\circ} \mathrm{C}$ for $24 \mathrm{~h}$ and the soluble protein content was analysed by a Bicinchoninic Acid Assay (Pierce ${ }^{\mathrm{TM}}$ BCA Protein Assay Kit, Thermo Fisher $^{\mathrm{TM}}$, USA). The same sample preparation process was applied without a buffer in duplicate for measuring the $\mathrm{pH}$ over storage time at $-20{ }^{\circ} \mathrm{C}$.

\subsection{Differential scanning calorimetry (DSC)}

Differential Scanning Calorimetry was used to identify the onset temperature for ice crystal melting and to determine the amount of unfrozen water at freezing conditions in the lesser mealworms (DSC 250, TA Instruments, New Castle, USA). Insects frozen at $-80{ }^{\circ} \mathrm{C}$ were homogenized by making use of a freeze miller (SPEX Freezer Mill 6875D, Instrument Solutions, Nieuwegein, NL), $\sim 15 \mathrm{mg}$ of sample was weighed in an aluminium pan, hermetically sealed and cooled to $-80{ }^{\circ} \mathrm{C}$ at a rate of $20{ }^{\circ} \mathrm{C} / \mathrm{min}$. After $5 \mathrm{~min}$ of equilibration, the insect samples were heated from $-80{ }^{\circ} \mathrm{C}$ to $60{ }^{\circ} \mathrm{C}$ at a rate of $5{ }^{\circ} \mathrm{C} / \mathrm{min}$, followed by equilibration of $2 \mathrm{~min}$. This cycle was repeated for one time (Syamaladevi et al., 2012). TRIOS software (v. 4.1.1.33073, TA Instruments) was used to analyse the thermograms. The percent of unfreezable water was calculated by making use of the area of the integrated endothermic peak at the range of $0{ }^{\circ} \mathrm{C}$, where the phase transition of ice into water takes place. Eq. (1) was used to estimate the unfreezable water of the insect, where the unfreezable water is the percent of freezable water divided by the total percent of water (Xanthakis, Havet, Chevallier, Abadie, \& Le-Bail, 2013).

$U F W \%=100-\frac{100 Q}{H_{f} W}$

where $U F W$ is the percent of unfreezable water, $Q$ the enthalpy of melting $(\mathrm{J} / \mathrm{g}), H_{f}$ the heat of fusion of ice into water equivalent to $333.50 \mathrm{~J} / \mathrm{g}$ of ice/water, and $W$ the total amount of water in larvae determined by drying at $105 \pm 2{ }^{\circ} \mathrm{C}$ to a constant mass.

\subsection{Protein electrophoresis}

An SDS-PAGE was carried out to gain insight in the composition of the proteins. The supernatant samples were diluted so that approximately $10 \mu \mathrm{g}$ of insect protein was loaded to each well in order to obtain visible bands. A 4-12\% Bis-Tris Protein Gel (NuPAGE ${ }^{\mathrm{TM}}$, Thermo Fisher $^{\mathrm{TM}}$, Carlsbad, CA USA) was used on an XCell SureLock ${ }^{\mathrm{TM}}$ Electrophoresis Cell (Novex $^{\circledast}$ Mini-Cell, Invitrogen $^{\mathrm{Tm}}$, Van Allen Way Carlsbad, CA, USA) together with a MES running buffer (NuPAGE ${ }^{\circledR}$ MES SDS Running Buffer 20X, Thermo Fisher ${ }^{\mathrm{TM}}$ ). The electrophoresis was carried out according to manufacturer's protocol. An Unstained Protein Standard (Novex $^{\circledR}$ Sharp, Thermo Fisher ${ }^{\mathrm{TM}}$ ), ranging from 3.5 to $260 \mathrm{kDa}$, was used as marker. Before starting the electrophoresis, $0.5 \mathrm{~mL}$ antioxidant (NuPAGE ${ }^{\mathrm{TM}}$, Thermo Fisher $^{\mathrm{TM}}$ ) was added to the buffer to keep the proteins in a reduced state during electrophoresis. After running the electrophoresis, the gel was stained with Coomassie Brilliant Blue R-250 (Bio-Rad, Hercules, CA, USA), scanned and analysed with Image Lab $^{\mathrm{TM}}$ Software (GS-900 ${ }^{\mathrm{TM}}$ Calibrated Densitometer, Bio-Rad, CA, USA).

\subsection{Microstructure}

To get a better understanding of the possible microstructural differences, a Mastersizer was used to determine the particle sizes in the supernatants, and Confocal Laser Scanning Microscopy (CLSM) was used to observe the temporal and spatial localisation of the protein and fat particles in the supernatants and the upper part of the pellets. This upper part was scraped off the surface by a small spatula.

The Mastersizer (Mastersizer 2000, Malvern, UK) was used in combination with the Mastersizer 2000 v5.22 software to analyse the supernatants. The pump speed was $800 \mathrm{rpm}$, a Refractive Index of 1.48 was chosen for the samples, and 1.33 for the dispersant (water). Each sample was added until approximately 5\% obscuration was reached. Data was perceived reliable if the residual number was below 1.0.

A confocal microscope Zeiss LSM510-META CLSM (Zeiss, GER) was employed to visualise the localisation of the particles. Fat and protein particles were stained respectively by the fluorescence dyes Bodipy 505/515 (0.5 mg/mL) and Rhodamine B (1\%). Bodipy was 1000 times diluted with water and Rhodamine B 500 times. $500 \mu \mathrm{L}$ of each dye was mixed with $500 \mu \mathrm{L}$ sample $(1 \times$ diluted) in an Eppendorf tube (CELL$\mathrm{STAR}^{\circledast}$, Greiner Bio-One GmbH, GER) and incubated for $5 \mathrm{~min}$. $200 \mu \mathrm{L}$ were then placed on a microscope slide, covered with a coverslip and observed under the microscope. An Argon laser with an excitation 
wavelength of $488 \mathrm{~nm}$ was used for the dye Bodipy, and a He-Ne laser with an excitation wavelength of $543 \mathrm{~nm}$ was used for Rhodamine B. Pictures of both the protein and fat particles were made with an EC Plan-Neofluar $20 \times / 0.5$ lens (Zeiss, GER) and compared.

\subsection{Colour development}

A colour analysis was carried out to observe the browning intensity over time. For the colour analysis, $1.5 \mathrm{~mL}$ of sample with a protein concentration of $1.5 \mathrm{w} / \mathrm{v} \%$ was put in a $4 \mathrm{~mL}$ cuvette (Cuvette PS, Sarstedt, GER) and diluted with $1.5 \mathrm{~mL}$ MilliQ water (PURELAB ${ }^{\circledR}$ Ultra, ELGA, UK). Pictures were taken at predetermined times (after 0, 2, 4 and $24 \mathrm{~h}$ at $20{ }^{\circ} \mathrm{C} \pm 2$ ) in IRIS VA400 (Alpha MOS, Instrument Solutions, Nieuwegein, NL) to ensure constant lighting conditions.

\subsection{Foam ability and stability}

To determine the foam ability and foam stability, $8 \mathrm{~mL}$ of supernatant $(1.5 \mathrm{w} / \mathrm{v} \%$ protein) was poured in a $15 \mathrm{~mL}$ Greiner tube (CELLSTAR $^{\circledast}$, Greiner Bio-One, NL) and shaken for $30 \mathrm{~s}$ to obtain a foam. The foam height (volume) was noted after respectively 0,1 and $24 \mathrm{~h}$ at $20{ }^{\circ} \mathrm{C} \pm 2$. The foam stability was computed as the percentage of foam volume at time $t$ in relation with the starting volume.

\subsection{Rheology}

An Anton Paar rheometer (MCR 302, Anton Paar GmbH, AT) was used to measure the gelling capacity of the samples. The protein concentrations of all samples were standardized to $1.5 \mathrm{w} / \mathrm{v} \%$ before use. $4.7 \mathrm{~mL}$ of sample was added to a concentric cylinder system (C-CC17/ T200/Ti and CC17/TI, Anton Paar GmbH, AT) and a thin layer of paraffin oil was added on top to prevent sample evaporation. A sequence of five programmes was written to form a gel and measure its capacities. First, the sample was heated from 25 to $90{ }^{\circ} \mathrm{C}$ with a rate of $3{ }^{\circ} \mathrm{C} / \mathrm{min}$, then it was held at $90^{\circ} \mathrm{C}$ for $60 \mathrm{~min}$, cooled down to $4{ }^{\circ} \mathrm{C}$, held at $4{ }^{\circ} \mathrm{C}$ for $60 \mathrm{~min}$, finalized by variating the strain from 0 till $1000 \%$ (amplitude sweep) at $4{ }^{\circ} \mathrm{C}$. For the first four programmes, the strain was set on $1 \%$ and the frequency at $1 \mathrm{~Hz}$. Measurement points were taken every $5 \mathrm{~s}$ during the entire run.

\subsection{Statistical analysis}

All experiments were performed in duplicate (technical replicates). IBM SPSS Statistics 23 was used for analysing the data by a One-Way ANOVA. Significant differences $(\mathrm{p}<0.05)$ were identified by a Post Hoc Tukey HSD test.

\section{Results and discussion}

\subsection{Characterization of samples upon frozen storage}

In Fig. 1 the distribution of the fractions obtained after processing of the samples stored at different storage times is reported, showing clear differences due to the storage time. The first clear observed trend is an increase of the pellet fraction (and a corresponding decrease in the supernatant fraction). The weight of the pellet fraction after 60 days of storage was $40.3 \%$ of total, compared to $12.8 \%$ of pellet for the control sample (stored at $-80^{\circ} \mathrm{C}$ ). The same trend can be observed in the supernatant fractions $(\mathrm{p}<0.05)$ : the sample stored for 60 days at $-20{ }^{\circ} \mathrm{C}$ having the lowest amount $(57.7 \%$ of the total), and the control sample the highest (85.3\%). No clear trend in change in the amount of material recovered in the cream layer was observed. Besides fraction distribution, the protein concentration of samples (Fig. A.1) stored at $-20{ }^{\circ} \mathrm{C}$ between 1 and 7 days decreased significantly $(\mathrm{p}<0.05)$ between 1 and 7 days, which corresponded to $1.7 \%$ versus $1.4 \%$ respectively ( $\mathrm{g}$ protein $/ 100 \mathrm{~mL}$ supernatant). The decrease in protein concentration explains the trend shown in Fig. 1 in the first week of frozen storage, but not upon prolonged storage as the concentration of soluble protein remained constant whilst the mass of the supernatant kept decreasing. Taken together, these findings suggest that upon storage at $-20{ }^{\circ} \mathrm{C}$, the amount of soluble protein decreased, whilst the amount of insoluble protein (pellet fraction) increased. A similar observation was also taken during prolonged frozen storage $\left( \pm 18{ }^{\circ} \mathrm{C}\right)$ of fish, were muscle proteins (both myosin and actin) denatured and formed insoluble fractions (Benjakul, Visessanguan, Thongkaew, \& Tanaka, 2005; Matsumoto, 1979). Several studies indicate that the loss in solubility could be caused by the formation of disulphide, hydrogen and hydrophobic bonds, which induce protein aggregation under freezing circumstances (Jiang, Hwang, \& Chen, 1988; Lim \& Haard, 1984; Tejada et al., 1996). From these data, it is likely that this also happens in insects under freezing circumstances.

\subsection{Enzymatic activity upon frozen storage}

DSC analysis was used to determine the onset temperature of ice melting and the amount of unfreezable water (Fig. 2). Pure water melts at temperatures above $\left(0{ }^{\circ} \mathrm{C}\right)$, changing its state from a solid to a liquid; while solutes are generally known to decrease the melting temperature. In Lesser mealworms, the onset of ice melting occurred at a temperature of $-32.5{ }^{\circ} \mathrm{C}$, similar to what found in different fish species (Tolstorebrov, Eikevik, \& Bantle, 2014). In addition, the normalized enthalpy of the freezing peak measured $169.97 \mathrm{~J} / \mathrm{g}$, meaning that $25 \%$ of water remained unfrozen also at $-32.5{ }^{\circ} \mathrm{C}$ (unfrozen water). These findings highlight the importance of the storage temperature, where a storage temperature of at least $-35^{\circ} \mathrm{C}$ can be recommended for storage of Lesser mealworms to control their quality.

The $\mathrm{pH}$ of supernatant decreased significantly over storage time of larvae stored at $-20{ }^{\circ} \mathrm{C}$, moving from 6.90 at day 1 to 6.54 after 60 days (Fig. A.2). Two hypotheses can be drawn to describe the $\mathrm{pH}$ decrease (i) release of hydrogen ions due to protein denaturation; (ii) increase of concentration of the solutes (Hoffman, 2012; Leygonie, Britz, \& Hoffman, 2011). Given that the percentage of unfrozen water ( $\pm 25 \%$ ) is relatively high, also compared to what was found in fish (Tolstorebrov et al., 2014), it is more likely that the $\mathrm{pH}$ decrease was caused by release of hydrogen ions due to protein denaturation occurring at freezing temperature.

An explanation can be found in anti-freeze proteins (AFPs). AFPs designate a class of proteins that are able to bind and inhibit the growth of macromolecular ice by decreasing the probability of ice nucleation. These proteins have been characterized in a variety of insects, including larvae of Tenebrio molitor (Graether \& Sykes, 2004). Given the taxonomical proximity of the two species, it is likely that AFPs acted as a limiting factor in ice formation, favouring enzymatic activity and protein denaturation reasonable. To support the instability of protein with unfrozen water, Tolstorebrov, Eikevik, and Bantle (2016) suggested that a protein stability was found at temperatures below the end of the freezing point, when the unfrozen water content is at its minimum. This hypothesis can also be ruled out considering that there was no modification of dry weight of the supernatants. Next to this, in fish, the glassy state/glass transition was found to be in the range between $-86.0{ }^{\circ} \mathrm{C}$ and $-68.0{ }^{\circ} \mathrm{C}$ (Tolstorebrov et al., 2014). Within the glassy state, a sharp inhibition of molecular mobility and a decrease in reaction rates occur (Champion, Le Meste, \& Simatos, 2000), suggesting that molecular mobility in Lesser mealworms could occur upon frozen storage at $-20{ }^{\circ} \mathrm{C}$, and be inhibited at $-80{ }^{\circ} \mathrm{C}$ as observed. In our DSC experiments, no clear $\mathrm{Tg}$ was observed, possibly due to sample complexity.

The protein composition was studied by SDS-PAGE, as shown in Fig. 3. A clear decrease in the abundance of the protein bands around $260 \mathrm{kDa}$ during prolonged frozen storage at $-20{ }^{\circ} \mathrm{C}$ can be observed. On the contrary, protein bands between 50 and $60 \mathrm{kDa}, 30 \mathrm{kDa}$ and around $3.5 \mathrm{kDa}$ increased upon storage. Accordingly, in previous 


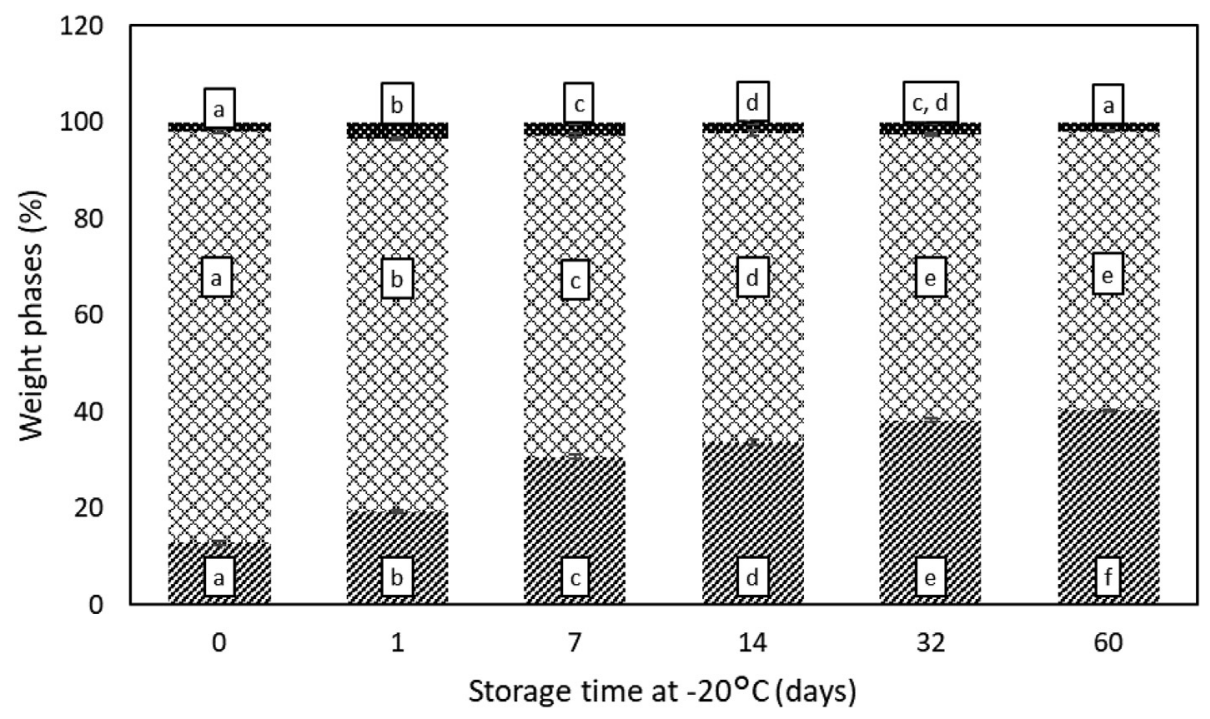

Fig. 1. Phase fractions after centrifugation for increasing storage times at $-20^{\circ} \mathrm{C}$. The weight of the phases is displayed as the percentage of the initial added weight of sample. Shaded bar, Pellet; crossed bar, supernatant; dotted bar, cream.

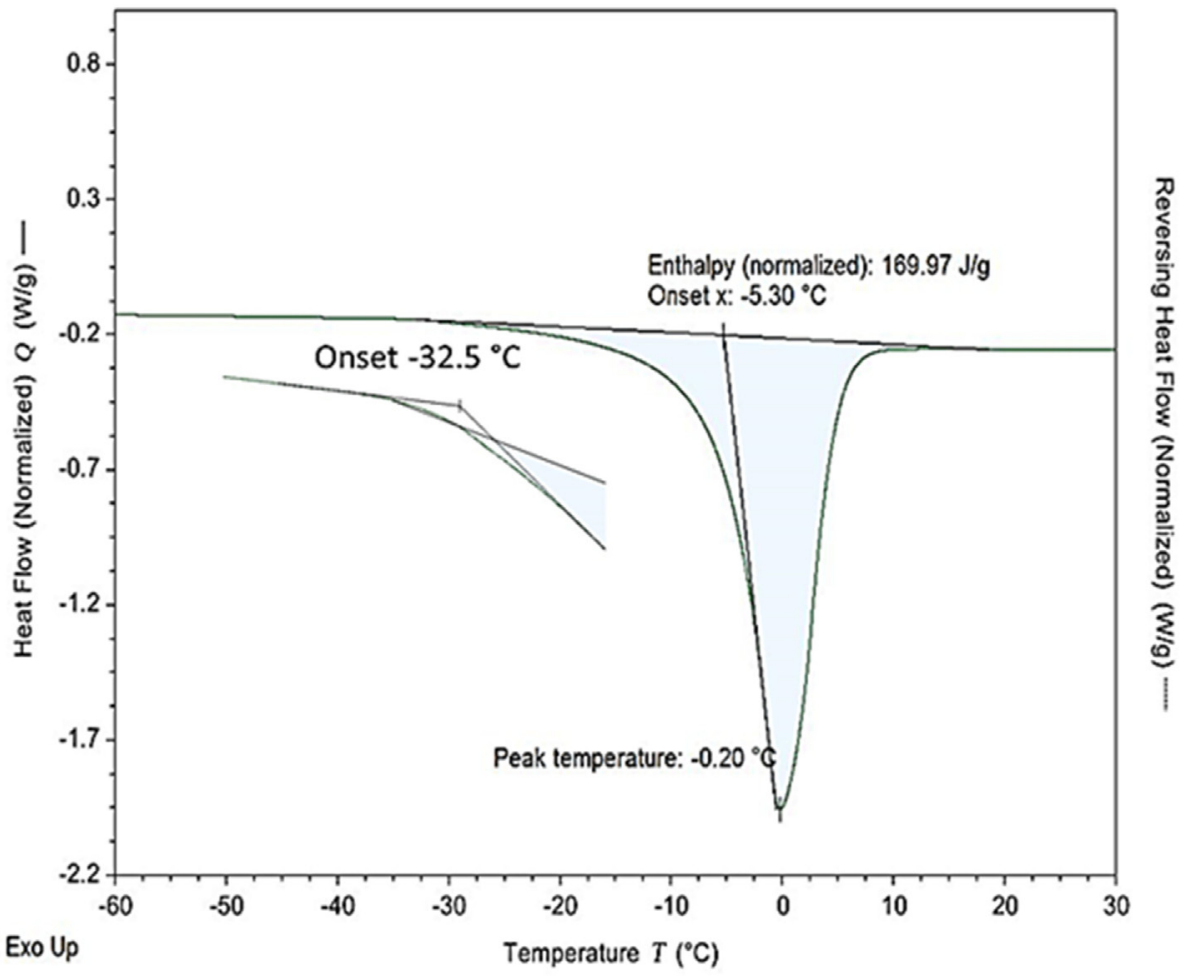

Fig. 2. Combined outcome DSC analysis of grinded frozen larvae. The onset temperature of ice melting and normalized enthalpy are highlighted.

studies run by our group (Janssen, 2018; Yi et al., 2013), larvae were stored at $-20{ }^{\circ} \mathrm{C}$ for several weeks and no bands around $260 \mathrm{kDa}$ could be seen. To corroborate this finding, in a more recent paper by Azzollini et al. (2018) the proteins were analysed immediately after blending and a clear protein band at $260 \mathrm{kDa}$ is visible. The bands at approximately $80 \mathrm{kDa}$ were the most abundant in this study, which is corresponding to findings of several studies who identify these proteins as muscular fibrillar proteins, resembling actin and tropomyosin (Azzollini et al., 2018; Yi, Van Boekel, \& Lakemond, 2017; Yi, Van Boekel, Boeren, \& Lakemond, 2016). The decrease in protein band strength of $260 \mathrm{kDa}$ indicates the insolubility/aggregation or hydrolysis of heavy chain myosin upon frozen storage (Matsumoto, 1979; Sikorski, Olley, Kostuch, \& Olcott, 1976; Yi et al., 2016). The increase in small molecular weight proteins ( 30 and $3.5 \mathrm{kDa}$ ) suggests protein hydrolysis, producing smaller peptides, and confirming protein denaturation upon storage. Furthermore, ice crystal formation could also induce damaging the mitochondria, causing enzyme release from mitochondria into the sarcoplasm, increasing enzymatic activity upon slow thawing (Benjakul \& Bauer, 2000; Hamm, 1979).

\subsection{Microstructure of supernatant fractions L. mealworm}

The particle sizes of the samples were determined by a Mastersizer, and a CLSM was used to visualize the protein and fat particles in the supernatants. The results are displayed in Fig. 4, Panel A and Panel B respectively. A clear increase in particle size during prolonged frozen 
Storage time at $-20^{\circ} \mathrm{C}$ (days)

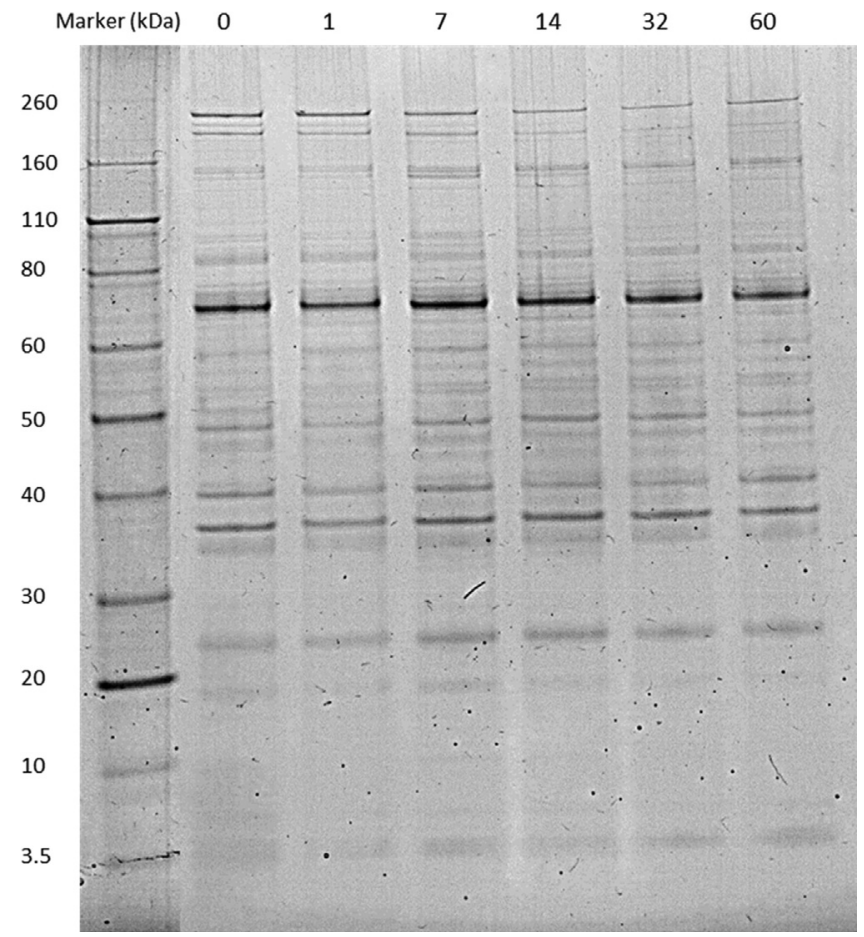

Fig. 3. SDS-PAGE of supernatant fraction obtained from A. diaperinus larvae stored for different times at $-20^{\circ} \mathrm{C}$.

storage time was visible. Initial particle size was found mainly at 0.1-1.0 $\mu \mathrm{m}$ (double bell curve), whereas aggregates with a particle size of $10 \mu \mathrm{m}$ were formed upon longer storage times (towards a single bell curve). CLSM observations support these findings, aggregates were formed very clearly upon frozen storage and moved towards the upper part of the pellets (Appendix, Fig. A.3). These findings together with the results of the SDS-PAGE are in line with several studies, indicating the aggregation of myosin heavy chains, probably caused by the formation of intermolecular S-S bonds (Matsumoto, 1979; Sikorski et al., 1976; Yi et al., 2016). During ice crystals formation, water molecules move away from the protein molecules, favouring protein aggregation next to myosin heavy chains through intermolecular cross-bonding (Matsumoto, 1979). Next to behaviour of the proteins, also the fat particles show some kind of aggregation, forming complexes with proteins. Keller and Kinsella (1973) found that lipid oxidation occurred in raw hamburgers during frozen storage at $-18{ }^{\circ} \mathrm{C}$, and Khayat and Schwall (1983) reported that binding of oxidised unsaturated lipids to proteins occurred in stored frozen seafood, resulting in the formation lipid-protein complexes. On top of this, Buttkus (1967) showed that products of oxidized fatty acids can react with myosin in solutions, and that this reaction is accelerated at $-20{ }^{\circ} \mathrm{C}$. These studies combined could support the formation of protein-lipid complexes upon frozen storage.

\subsection{Effect frozen storage on ingredient functionalities}

The effect of frozen storage time on colour development, foam ability, foam stability and rheology were studied as ingredient functionalities and displayed in Figs. A.4, 5 and 6.

The results of the colour development over time showed a clear visible increase in browning reaction in samples stored for a longer time at $-20{ }^{\circ} \mathrm{C}$ (Fig. A.4). In $24 \mathrm{~h}$ at room temperature, the supernatant obtained after melting the samples stored at $-20{ }^{\circ} \mathrm{C}$ turned brown much faster than the control. Leni et al. (2019) found that tyrosine is a substrate for phenol oxidase activity, which is oxidized into o-quinones in the final reaction step. During aqueous extraction, this tyrosine can further react and produce melanins, causing browning reactions. The same author reported no enzymatic browning reaction when insects were blanched as a killing method compared to slowly killing by freezing. This has been related to tyrosine degradation occurring in frozen larvae, compared to blanching. Although in this paper, an analogous killing method was used (fast with liquid nitrogen), and still clear browning was visible, it is likely that phenoloxidase is still active during frozen storage at $-20{ }^{\circ} \mathrm{C}$. To support this finding, Janssen (2018) also found activities of L-tyrosine and L-DOPA in Lesser mealworms, indicating phenoloxidase as a key player in browning.

Next to the colour development, the foam ability and stability were also studied and results are shown in Fig. 5. The starting foam height increased significantly $(\mathrm{p}<0.05)$ after 60 days of frozen storage, starting from a volume of 0.6 at time 0 up to 1.85 after 60 days. Between 1 and 7 days of storage, the foam stability significantly ( $\mathrm{p}<0.05$ ) increased from 39.4 to $89.2 \%$. The foam stability after $24 \mathrm{~h}$ showed a significant $(\mathrm{P}<0.05)$ large linear increase as function of time $\left(\mathrm{R}^{2}>0.81\right)$ during prolonged frozen storage. Sarker, Wilde, and Clark (1995) established that a polyphenol compound can alter an interfacial layered structure due to interactions with adsorbed proteins at the air/water foam interface, thereby enhancing the foam stability. In another study, cross linking of whey proteins occurred due to polyphenol oxidase activity, increasing their foam capacity and stability (Wu et al., 2013). Since it is reasonable that polyphenol oxidase plays a big role during frozen storage of Lesser mealworms, polymerization of phenol compounds can probably occur, thus enhancing the foam ability and stability. Other factors contributing to the increase in foaming properties in our research could be the increase of protein denaturation, exposure of hydrophobic regions and formation of aggregates. Kato, Tsutsui, Matsudomi, Kobayashi, and Nakai (1981) found that foaming properties of proteins improved by protein denaturation, due to the increase in exposure of hydrophobic residues. On top of this, smaller molecular weight proteins show better mobility, hence faster diffusing to the interface, reducing the interfacial tension, facilitating foam formation (Lazidis et al., 2016). Finally, the presence of some protein aggregates can increase the viscoelasticity of the interface and fill up the free space between air and fluid, increasing the foam stabilization and preventing drainage (Lazidis et al., 2016; Rullier, Novales, \& Axelos, 2008). Taken together, storage of insects at $-20{ }^{\circ} \mathrm{C}$ caused changes in protein structure, which ultimately modified their functionality. In addition, part of the functionality may also have been affected by the types of proteins left soluble in the supernatant, contributing to a different functional behaviour.

The last ingredient functionality studied was the effect of frozen storage on gel characteristics. Since the protein concentration in the supernatant varied upon cold storage, the protein concentration was adapted to the lowest concentration by diluting the samples to a protein concentration of approximately $1.4 \%$ before rheology analysis. All samples were able to form a gel and the $\mathrm{G}^{\prime}$ (storage modulus) and $\mathrm{G}^{\prime \prime}$ (loss modulus) were determined and plotted against the strain, both on a logarithmic scale. The limit of the linear viscoelastic (LVE) region, also called the critical strain $(\gamma \mathrm{c})$, was described as the strain amplitude at which G' decreased by $5 \%$ from its maximum value (Eleya, Ko, \& Gunasekaran, 2004). The crossover point of $G^{\prime}$ and $G^{\prime \prime}$ was determined from the same plot, which indicates the change in viscoelastic behaviour from elastic solid-like to viscous liquid-like. This plot was made for all samples, for which an example can be found in Appendix A, Fig. A.5. The combined results of the critical strain and the crossover point are presented in Fig. 6. Both the critical strain as well as the crossover point did increase, but did not show a clear trend during the storage time. The critical strain was significant different $(\mathrm{p}<0.05)$ between the samples stored for 0 days at $-20{ }^{\circ} \mathrm{C}(3.99 \%)$ and stored for 60 days at $-20{ }^{\circ} \mathrm{C}(6.87 \%)$. All samples showed an LVE region, implying the existence of an entangled gel networks in all samples. The increase in critical strain upon frozen storage time suggests that disruption of the 

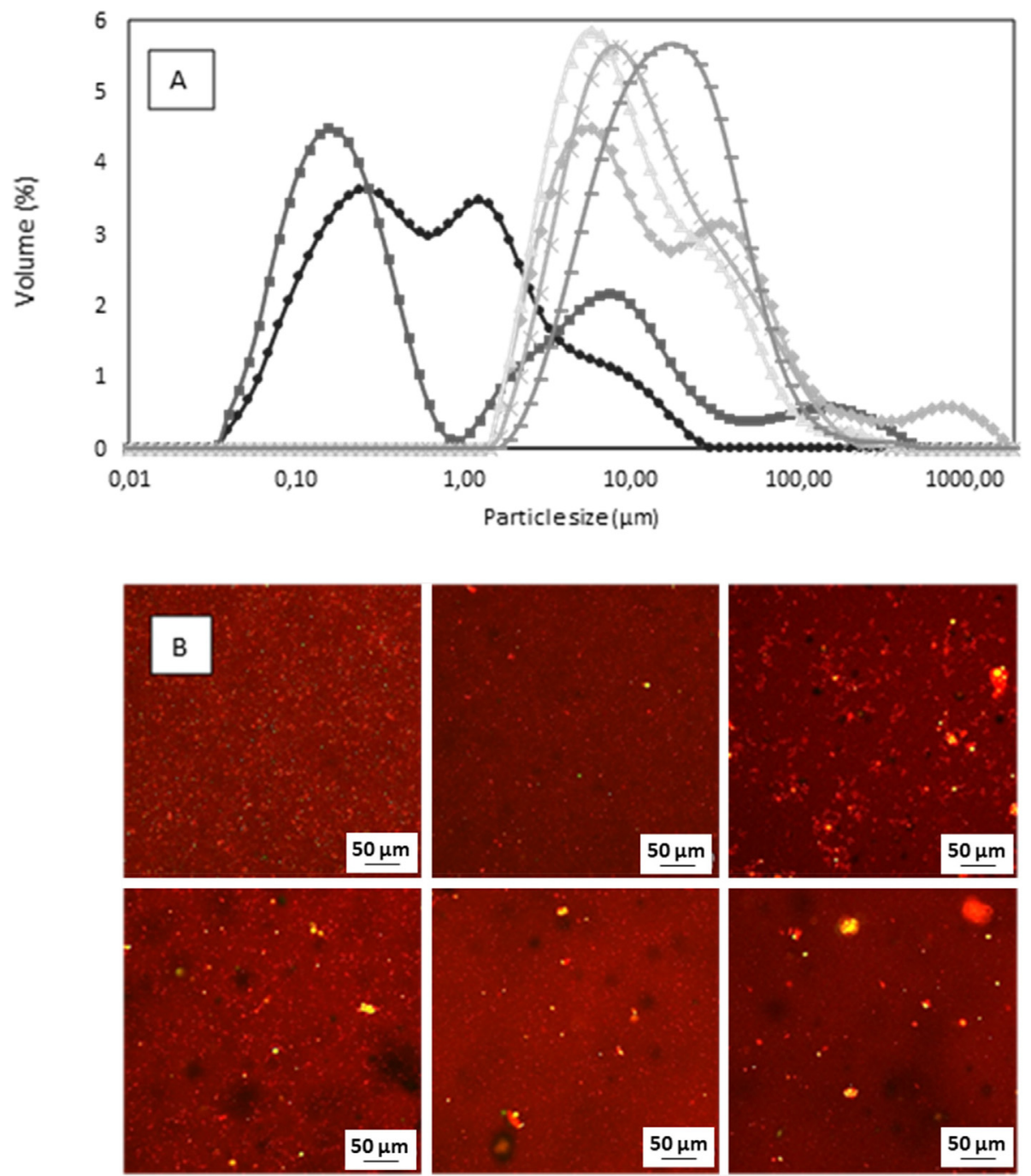

Fig. 4. Panel A: modification of the particle size in the supernatant of $A$. diaperinus larvae stored at $-20^{\circ} \mathrm{C}$ for different time. circle, 0 days; square, 1 day; diamond: 7 days; triangle, 14 days; cross, 32 days; bar, 60 days. Panel B: Visualisation of protein (red) and fat (yellow) particles in supernatants. Left to right, top to bottom: 0 , $1,7,14,32$ and 60 days of frozen storage at $-20^{\circ} \mathrm{C}$. (For interpretation of the references to colour in this figure legend, the reader is referred to the web version of this article.)

gel network happened at higher strains. On top of this, with increasing crossover point, the gel turned into a liquid like suspension at a higher strain when stored for a longer time at $-20{ }^{\circ} \mathrm{C}$, from a strain of $119.75 \%$ (0 days) towards a strain of $249 \%$ (60 days). This can be explained by the fact that the entanglements of the network increased, making the network more stable (Silverman et al., 2017), which is in line with the results of the microstructural results in the present study. It was also suggested from the SDS-PAGE results (Fig. 3) that some myofibrillar proteins of insect muscle denatured and aggregated upon frozen storage, which could be associated with the formation of disulphide (Jiang et al., 1988), suggesting the increase in entanglement ability.

\section{Conclusions}

Frozen storage of Lesser mealworms resulted in two major phenomena: loss of protein solubility and formation of fat-protein aggregates. These aggregates were likely formed due to an increased mobility and enzymatic activity at $-20{ }^{\circ} \mathrm{C}$ because of the high amount of unfreezable water, likely caused by the presence of anti-freezing proteins (AFPs) in larvae. Heavy chain myosin aggregated, and small molecular weight proteins were formed. These molecular changes increased the browning reactions during and after processing, caused by phenoloxidase activity during frozen storage. The foaming ability, foam stability and gel network stability increased upon frozen storage. Most of the molecular changes occurred in the first week of frozen storage. Existing studies about insect's ingredient functionalities should be revised considering the effect of frozen storage on the observed characteristics. For research purposes, a storage temperature of $-80{ }^{\circ} \mathrm{C}$ is advisable to ensure consistency in literature of insect ingredient functionalities. Tailored applicative studies are needed to identify the minimum industrial storage temperature that consents stability of insect biomass for specific application without wasting refrigeration energy.

\section{Funding}

This study was supported by the Norwegian Research Council, project ENTOFÔR: from waste to resource, grant number 268344.

\section{CRediT authorship contribution statement}

M.L.J. Wessels: Investigation, Methodology. D. Azzollini: Conceptualization, Writing - original draft, Writing - review \& editing. 


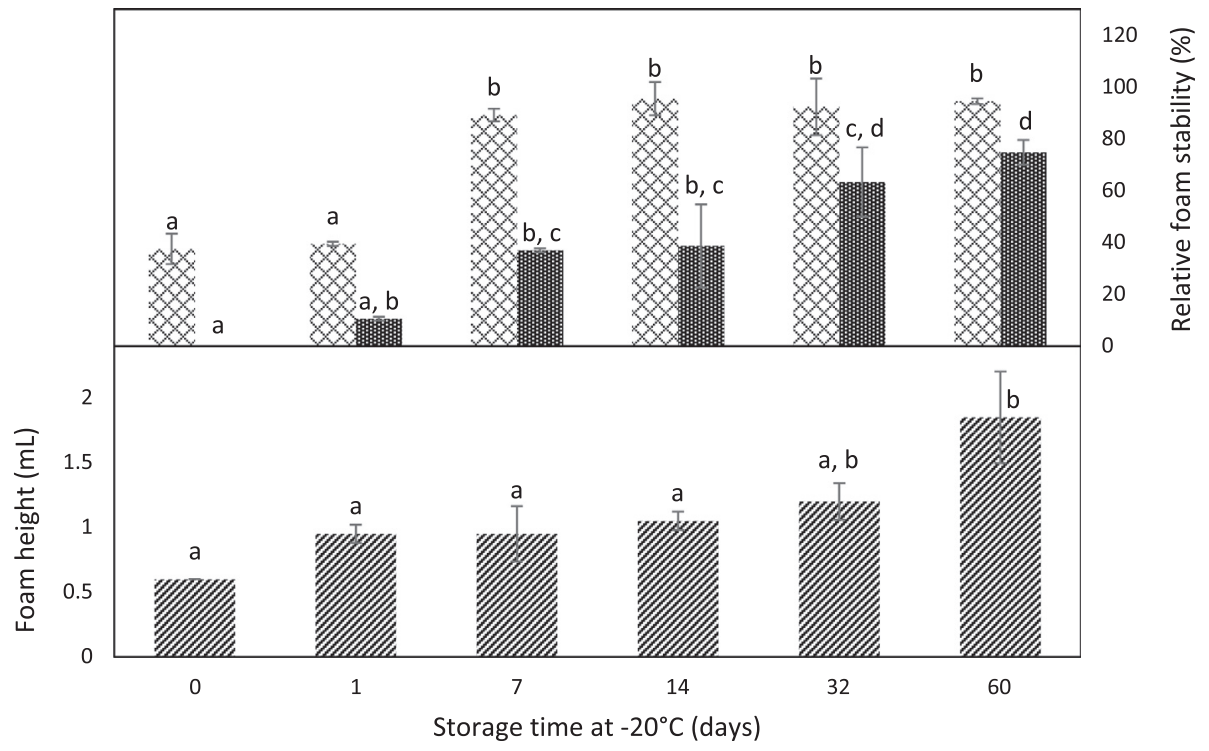

Fig. 5. Starting foam height and foam stability obtained by upon frozen storage at $-20^{\circ} \mathrm{C}$. Top Panel reported the foam stability described as the percentage of foam volume in relation with the starting volume after 1 and $24 \mathrm{~h}$. Crossed bars, $1 \mathrm{~h}$; dotted bar $24 \mathrm{~h}$. Bottom panel show the foam height after $1 \mathrm{~h}$.

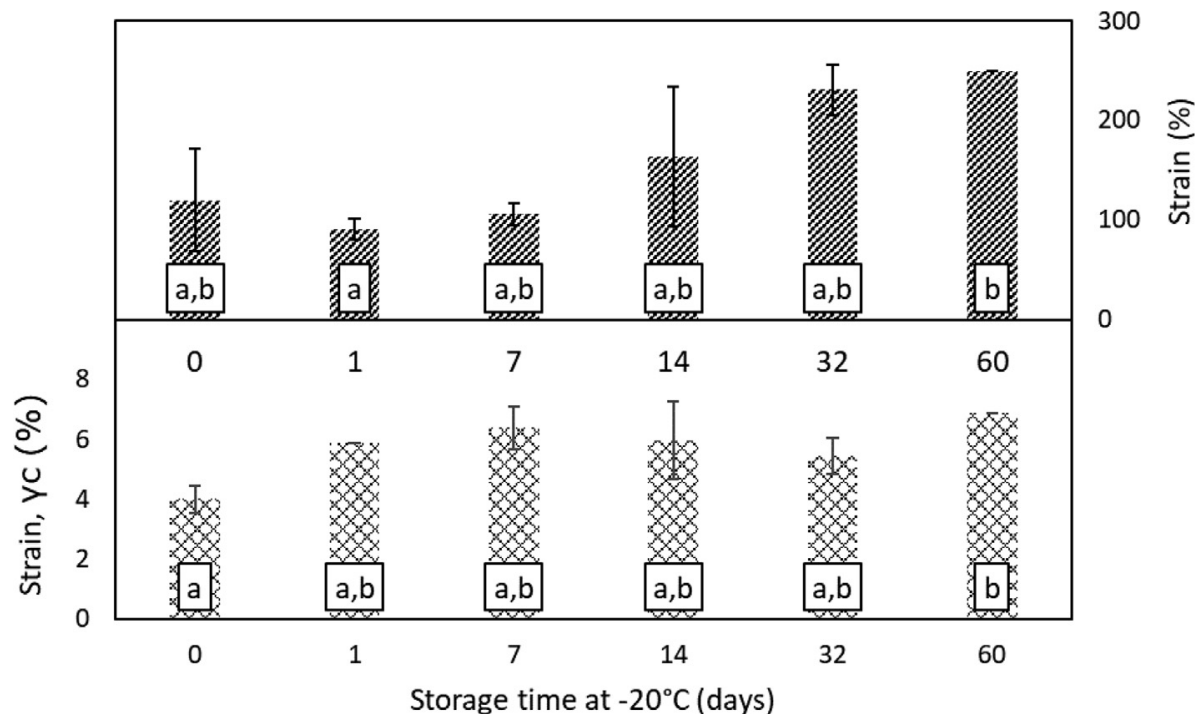

Fig. 6. Critical strain and crossover point of the A. diaperinus supernatant upon frozen storage at $-20{ }^{\circ} \mathrm{C}$. Bottom panel Critical strain $\mathrm{G}^{\prime}(\gamma \mathrm{c})$; top panel, Crossover point $\mathrm{G}^{\prime}$ and $\mathrm{G}^{\prime \prime}$.

V. Fogliano: Supervision, Writing - review \& editing.

\section{Declaration of Competing Interest}

The authors declare that they have no known competing financial interests or personal relationships that could have appeared to influence the work reported in this paper.

\section{Appendix A. Supplementary data}

Supplementary data to this article can be found online at https:// doi.org/10.1016/j.foodchem.2020.126649.

\section{References}

Ali, S., Zhang, W., Rajput, N., Khan, M. A., Li, C.-B., \& Zhou, G.-H. (2015). Effect of multiple freeze-thaw cycles on the quality of chicken breast meat. Food Chemistry, $173,808-814$.

Azzollini, D., Wibisaphira, T., Lakemond, C., \& Fogliano, V. (2018). Toward the design of insect-based meat analogue: The role of calcium and temperature in coagulation behavior of Alphitobius diaperinus proteins. LWT.

Benjakul, S., \& Bauer, F. (2000). Physicochemical and enzymatic changes of cod muscle proteins subjected to different freeze-thaw cycles. Journal of the Science of Food and Agriculture, 80(8), 1143-1150.

Benjakul, S., Visessanguan, W., Thongkaew, C., \& Tanaka, M. (2005). Effect of frozen storage on chemical and gel-forming properties of fish commonly used for surimi production in Thailand. Food Hydrocolloids, 19(2), 197-207.

Buttkus, H. (1967). The reaction of myosin with malonaldehyde. Journal of Food Science, 32(4), 432-434.

Champion, D., Le Meste, M., \& Simatos, D. (2000). Towards an improved understanding of glass transition and relaxations in foods: Molecular mobility in the glass transition range. Trends in Food Science \& Technology, 11(2), 41-55.

Dossey, A., Tatum, J., \& McGill, W. (2016). Modern insect-based food industry: Current status, insect processing technology, and recommendations moving forward Insects as Sustainable Food Ingredients. Elsevier113-152.

Eleya, M. O., Ko, S., \& Gunasekaran, S. (2004). Scaling and fractal analysis of viscoelastic properties of heat-induced protein gels. Food Hydrocolloids, 18(2), 315-323.

Graether, S. P., \& Sykes, B. D. (2004). Cold survival in freeze-intolerant insects: The structure and function of $\beta$-helical antifreeze proteins. European Journal of Biochemistry, 271(16), 3285-3296.

Hamm, R. (1979). Delocalization of mitochondrial enzymes during freezing and thawing of skeletal muscle. Advances in Chemistry Series, 180, 191-204.

Hoffman, C. L. T. B. L. (2012). Impact of freezing and thawing on the quality of meat: 
Review. Meat Science, 91, 93-98.

Janssen, R. H. (2018). Potential of insect proteins for food and feed. Wageningen University.

Jiang, S. T., Hwang, D. C., \& Chen, C. S. (1988). Effect of storage temperatures on the formation of disulfides and denaturation of milkfish actomyosin (Chanos chanos). Journal of Food Science, 53(5), 1333-1335.

Kato, A., Tsutsui, N., Matsudomi, N., Kobayashi, K., \& Nakai, S. (1981). Effects of partial denaturation on surface properties of ovalbumin and lysozyme. Agricultural and Biological Chemistry, 45(12), 2755-2760.

Keller, J. D., \& Kinsella, J. E. (1973). Phospholipid changes and lipid oxidation during cooking and frozen storage of raw ground beef. Journal of Food Science, 38(7), 1200-1204.

Khayat, A., \& Schwall, D. (1983). Lipid oxidation in seafood. Food Technology (USA).

Lazidis, A., Hancocks, R., Spyropoulos, F., Kreuß, M., Berrocal, R., \& Norton, I. (2016). Whey protein fluid gels for the stabilisation of foams. Food Hydrocolloids, 53, 209-217.

Leni, G., Caligiani, A., \& Sforza, S. (2019). Killing method affects the browning and the quality of the protein fraction of Black Soldier Fly (Hermetia illucens) prepupae: A metabolomics and proteomic insight. Food Research International, 115, 116-125.

Leygonie, C., Britz, T. J., \& Hoffman, L. C. (2011). Oxidative stability of previously frozen ostrich Muscularis iliofibularis packaged under different modified atmospheric conditions. International Journal of Food Science \& Technology, 46(6), 1171-1178.

Lim, H., \& Haard, N. (1984). Protein insolubilization in frozen Greenland halibut (Reinhardtius hippoglossoides). Journal of Food Biochemistry, 8(3), 163-187.

Matsumoto, J. (1979). Denaturation of fish muscle proteins during frozen storage. Proteins at Low Temperature, 206-224.

Ortiz, J. C., Ruiz, A. T., Morales-Ramos, J., Thomas, M., Rojas, M., Tomberlin, J., .. Jullien, R. (2016). Insect mass production technologies Insects as Sustainable Food Ingredients. Elsevier153-201.

Payne, S., Sandford, D., Harris, A., \& Young, O. (1994). The effects of antifreeze proteins on chilled and frozen meat. Meat Science, 37(3), 429-438.

Rullier, B., Novales, B., \& Axelos, M. A. (2008). Effect of protein aggregates on foaming properties of $\beta$-lactoglobulin. Colloids and Surfaces A: Physicochemical and Engineering Aspects, 330(2-3), 96-102.

Sarker, D. K., Wilde, P. J., \& Clark, D. C. (1995). Control of surfactant-induced destabilization of foams through polyphenol-mediated protein-protein interactions. Journal of Agricultural and Food Chemistry, 43(2), 295-300.

Sikorski, Z. E., Olley, J., Kostuch, S., \& Olcott, H. S. (1976). Protein changes in frozen fish. Critical Reviews in Food Science \& Nutrition, 8(1), 97-129.
Silverman, J. R., Zhang, Q., Pramanik, N. B., Samateh, M., Shaffer, T. M., Sagiri, S. S., ... John, G. (2017). Radiation-responsive esculin-derived molecular gels as signal enhancers for optical imaging. ACS applied materials \& interfaces, 9(49), 43197-43204.

Syamaladevi, R. M., Manahiloh, K. N., Muhunthan, B., \& Sablani, S. S. (2012). Understanding the influence of state/phase transitions on ice recrystallization in Atlantic salmon (Salmo salar) during frozen storage. Food Biophysics, 7(1), 57-71.

Tejada, M., Careche, M., Torrejón, P., Del Mazo, M., Solas, M., Garcia, M., \& Barba, C. (1996). Protein extracts and aggregates forming in minced cod (Gadus morhua) during frozen storage. Journal of Agricultural and Food Chemistry, 44(10), 3308-3314.

Tolstorebrov, I., Eikevik, T., \& Bantle, M. (2014). A DSC study of phase transition in muscle and oil of the main commercial fish species from the North-Atlantic. Food Research International, 55, 303-310.

Tolstorebrov, I., Eikevik, T. M., \& Bantle, M. (2016). Effect of low and ultra-low temperature applications during freezing and frozen storage on quality parameters for fish. International Journal of Refrigeration, 63, 37-47.

Tzompa-Sosa, D. A., Yi, L., van Valenberg, H., \& Lakemond, C. (2019). Four insect oils as food ingredient: Physical and chemical characterisation of insect oils obtained by an aqueous oil extraction. Journal of Insects as Food and Feed, 1-14.

Van Huis, A., Van Itterbeeck, J., Klunder, H., Mertens, E., Halloran, A., Muir, G., \& Vantomme, P. (2013). Edible insects: Future prospects for food and feed security. Food and Agriculture Organization of the United Nations.

Wu, J., Gao, J., Chen, H., Liu, X., Cheng, W., Ma, X., \& Tong, P. (2013). Purification and characterization of polyphenol oxidase from Agaricus bisporus. International Journal of Food Properties, 16(7), 1483-1493.

Xanthakis, E., Havet, M., Chevallier, S., Abadie, J., \& Le-Bail, A. (2013). Effect of static electric field on ice crystal size reduction during freezing of pork meat. Innovative Food Science \& Emerging Technologies, 20, 115-120.

Yi, L., Lakemond, C. M. M., Sagis, L. M. C., Eisner-Schadler, V., van Huis, A., \& van Boekel, M. A. J. S. (2013). Extraction and characterisation of protein fractions from five insect species. Food Chemistry, 141(4), 3341-3348. https://doi.org/10.1016/j. foodchem.2013.05.115.

Yi, L., Van Boekel, M. A., Boeren, S., \& Lakemond, C. M. (2016). Protein identification and in vitro digestion of fractions from Tenebrio molitor. European Food Research and Technology, 242(8), 1285-1297.

Yi, L., Van Boekel, M., \& Lakemond, C. (2017). Extracting Tenebrio molitor protein while preventing browning: Effect of $\mathrm{pH}$ and $\mathrm{NaCl}$ on protein yield. Journal of Insects as Food and Feed, 3(1), 21-31. 